\title{
RAKYAT MEMPERKUAT KENDALINYA TERHADAP NEGARA
}

\author{
Merphin Panjaitan \\ merphinpanjaitan@gmail.com
}

\begin{abstract}
The people's goal to established the a state is to get better life, justice, secure and welfare. But in the New Order, injustice was almost happened in all fields of lives, which was then fall into an economic crisis leaving broad poverty, unemployment, backward education and corruption. Those New Order's diseases are still continue up till now, although reformation has been continued for more than 10 years. In reality the state's power is not always used to serve its people. Thus, people has to tightened its control toward state, since when once loose its control, state's power will be misused only for the interest of the ruler and at the same time forget the people who actually is the owner of the state. The state is owned by people for the common good and that kind of state is named democratic state that its process of execution must be under people's control. For that purpose it needed a kind of political interaction between state-society which is peaceful, secure, fairness and having trust to each other. That interaction needs appropriate condition, among other things are limited state power, power division based on check and balance principle, general election, effective political participation, regional autonomy and reformation of the behavior of society and state.
\end{abstract}

Keywords: State power, People's control, Democratic state, Behavior reform of state and society

\section{Pendahuluan}

Sejarah pendirian negara Republik Indonesia memperlihatkan, bahwa rakyat Indonesia mendirikan negara untuk mendapatkan kehidupan yang lebih baik, lebih sehat, lebih kuat, lebih maju, lebih sejahtera dan lebih adil. Pada tgl. 1 Juni 1945, Soekarno mendapat giliran berbicara di dalam Sidang Badan Penyelidik Usaha-Usaha Persiapan Kemerdekaan Indonesia, antara lain menyatakan sebagai berikut:

Dasar itu ialah dasar mufakat, dasar perwakilan, dasar permusyawaratan. Negara Indonesia bukan satu negara untuk satu orang, bukan satu negara untuk satu golongan, walaupun golongan kaya. Tetapi kita mendirikan negara "semua buat semua", "satu buat semua", "semua buat satu". Saya yakin, bahwa syarat yang mutlak untuk kuatnya negara Indonesia ialah permusyawaratan perwakilan ...

Selanjutnya Soekarno menyatakan,

Apa-apa yang belum memuaskan,kita bicarakan di dalam permusyawaratan. Badan Perwakilan inilah tempat kita untuk mengemukakan untutan- 
tuntutan.......Di sinilah kita usulkan kepada pemimpin-peminpin rakyat, apaapa yang kita rasa perlu bagi perbaikan. ${ }^{1}$

Usulan ini diterima dan Republik Indonesia menjadi negara yang berkedaulatan rakyat sejak pembentukannya,seperti yang termuat dalam Pembukaan UndangUndang Dasar Negara Republik Indonesia Tahun 1945 ... yang terbentuk dalam suatu susunan Negara Republik Indonesia yang berkedaulatan rakyat ...

Hatta dalam tulisannya berjudul Demokrasi Asli Indonesia dan Kedaulatan Rakyat mengemukakan antara lain sebagai berikut:

Sebab itu, kalau Indonesia mau mendapat pemerintahan yang berdasar demokrasi, tidak boleh kita menoleh ke belakang. Kita harus melanjutkan "demokrasi asli "menjadi Kedaulatan Rakyat, ...Pendek kata: Daulat Tuanku mesti diganti dengan Daulat Rakyat! Tidak lagi seorang bangsawan, bukan pula seorang uanku, melainkan rakyat sendiri yang raja atas dirinya. Inilah dasar pemerintahan rakyat, dasar demokrasi tulen. ${ }^{2}$

Melalui tulisannya ini Hatta ingin menekankan bahwa di masa lalu berlaku Daulat Tuanku, dan di dalam Indonesia Merdeka berlaku Daulat Rakyat. Semua manusia setara, dan secara bersama-sama dalam satu negara disebut sebagai rakyat si pemegang kedaulatan atas negara. Gelombang nilai kesetaraan yang berkembang di Indonesia sangat kuat, dan hasilnya negara Republik Indonesia disepakati sebagai negara yang berkedaulatan rakyat. Republik Indonesia adalah negara demokrasi "semua buat semua", "satu buat semua, semua buat satu".

Rakyat mendirikan negara dan berdaulat atas negara tersebut. Negara harus melayani rakyat, dan untuk itu negara harus berada dalam kendali rakyat. Republik Indonesia didirikan oleh rakyat Indonesia karena negara dibutuhkan untuk mewujudkan kehidupan bersama yang lebih baik bagi rakyat seluruhnya. Republik Indonesia didirikan untuk kepentingan rakyat Indonesia, bukan rakyat Indonesia diadakan supaya negara Republik Indonesia dapat dibentuk. Rakyat sipemilik dan negara adalah alat.

John Locke dalam bukunya berjudul Two Treatises of Civil Government, Bagian Kedua, Pasal 87, antara lain menyatakan:

“... Manusia lahir, seperti sudah dibuktikan, dengan hak kebebasan sempurna dan menikmati dengan tanpa hambatan semua hak dan privilese hukum alam, tidak beda dengan manusia yang lain, atau sejumlah manusia di dunia. Oleh karena itu, dari kodratnya manusia mempunyai kekuasaan untuk tidak hanya menjaga kelestarian barang hak miliknya - yakni hidupnya, kebebasannya, tanah miliknya-

1 Lih. Saafroedin Bahar dkk. 1995. Hal 77. Badan Penyelidik Usaha-Usaha Persiapan Kemerdekaan Indonesia dalam Masa Sidang Pertama dari tgl. 28 Mei - 1 Juni 1945, membicarakan berbagai hal yang perlu dipersiapkan untuk kemerdekaan Indonesia, termasuk tentang dasar negara Indonesia.

${ }^{2}$ Mohammad Hatta. 1976. Kumpulan Karangan. Jakarta: Penerbit Bulan Bintang. Hal. 127. 
terhadap usaha orang lain yang merugikan dan memperdayakannya, tetapi juga untuk menjatuhkan putusan dan hukuman terhadap pelanggaran hukum yang dilakukan orang lain, ... tidak ada masyarakat politis yang dapat terus barlangsung tanpa memiliki kekuasaan untuk menjaga kelestarian hak milik, dan untuk tujuan itu menghukum pelanggaran hukum yang terjadi dalam masyarakat itu, maka masyarakat politis dapat ada hanya apabila setiap anggotanya telah melepaskan kekuasaan alami dan menyerahkannya kepada masyarakat politis ${ }^{3}$.

Pemikiran John Locke ini, menggambarkan manusia dalam keadaan alamiah, asal mula masyarakat politis dan tujuan pembentukannya. Dalam keadaan alamiah manusia mempunyai hak hidup, hak kebebasan dan hak milik. Untuk menjamin terpenuhinya hak alamiah ini, manusia membentuk masyarakat politik yang diberi kuasa untuk menjaga kelestarian hak-hak tersebut. Setiap anggota dalam masyarakat tersebut melepaskan kekuasaan alami untuk menghukum dan menyerahkannya kepada masyarakat politik, yang sekarang kita kenal sebagai negara. Pemikiran ini memperlihatkan asal mula pembentukan negara dan untuk apa negara dibentuk. Pada mulanya adalah hak alamiah yang melekat pada semua manusia dalam keadaan alamiah, sebelum ada negara. Kemudian untuk menjamin pemenuhan hak tersebut manusia membentuk negara dan mempercayakan kekuasaan alami menjadi kekuasaan negara.

Mengikuti jalan pikiran John Locke ini, untuk memahami landasan pemikiran negara demokrasi, perlu dijawab pertanyaan berikut. Siapa berhak mendapatkan apa? Siapa berkuasa melakukan apa, bagaimana kekuasaan itu didapat, dan kepada siapa kekuasaan tersebut dipertanggungjawabkan?

Rakyat mendirikan negara demokrasi sebagai suatu tatanan kenegaraan untuk kebaikan bersama. Dan kebaikan bersama adalah penerapan martabat manusia dalam cara dan tujuan negara. Martabat manusia adalah gabungan dari hak alamiah manusia, kapasitas alamiah manusia dan tugas alamiah manusia. Hak alamiah manusia adalah hak asasi manusia, antara lain:hak hidup, hak kebebasan, hak kesetaraan, hak memiliki dan hak mengejar kebahagiaan. Kapasitas alamiah manusia adalah akal dan nurani manusia. Tugas alamiah manusia adalah mempertahankan kelanggengan bangsa manusia dan menatalayani alam semesta ini beserta isinya. Martabat manusia adalah pemberian Tuhan Sang Pencipta kepada semua manusia,tanpa kecuali.

Secara universal martabat manusia dinyatakan dalam Pasal 1 Deklarasi Universal Hak Asasi Manusia, yang berbunyi:

All human beings are born free and equal in dignity and rights. They are endowed with reason and conscience and should act towards one another in a spirit of brotherhood. (Setiap orang dilahirkan merdeka dan mempunyai martabat

\footnotetext{
${ }^{3}$ John Locke. 2006. Two Treaties of Civil Government. Hal. 76.
} 
serta hak yang sama. Mereka dikaruniai akal dan nurani dan hendaknya bergaul satu sama lain dalam semangat persaudaraan).

Di Indonesia kebaikan bersama, yaitu penerapan martabat manusia dalam cara dan tujuan negara Republik Indonesia dimuat dalam Pembukaan UndangUndang Dasar Negara Republik Indonesia Tahun 1945.4 Demokrasi mengakui bahwa semua manusia setara, mempunyai kedudukan yang sama dihadapan hukum dan pemerintahan.Demokrasi menjamin pemenuhan hak asasi manusia,antara lain hak hidup, hak kebebasan, hak kesetaraan, hak memiliki dan hak mengejar kebahagiaan.

Logika kesetaraan menuntut perlakuan yang sama terhadap semua pemikiran warganegara dalam penetapan kebijakan publik, dan perlakuan yang sama dalam memperjuangkan kepentingannya. Tidak ada yang diabaikan dan tidak ada yang diistimewakan. Semuanya setara, baik sebagai manusia maupun sebagai warganegara. Semakin banyak warganegara yang ikut dalam proses penyelenggaraan negara, semakin besar kesesuaian antara kebijakan negara dengan kehendak rakyat. Setiap warganegara harus dianggap lebih mengetahui kepentingannya dalam kehidupan kenegaraan, dibanding dengan pihak manapun. Itulah asumsi dari prinsip kesetaraan politik. Bagaimanapun, kebijakan negara yang disusun berdasarkan tuntutan masyarakat luas akan lebih mendekati kehendak rakyat daripada disusun berdasarkan keinginan sedikit orang. Semua warganegara, secara pribadi ataupun kelompok, mempunyai hak dan kesempatan yang sama dalam pembuatan kebijakan publik dan dalam mendapatkan jabatan publik. Kesempatan untuk menduduki jabatan-jabatan kenegaraan, ukurannya bukan asal-usul, ras, suku, agama, kedudukan, atau kekayaan, tetapi ditentukan oleh dukungan dan pilihan rakyat. Dalam kesetaraan manusia, tetap ada pemimpin yang memerintah, tetapi mereka dipilih oleh yang diperintah dari antara mereka sendiri. Setiap upaya untuk membeda-bedakan martabat manusia, apapun alasannya adalah pelecehan terhadap martabat manusia.

Kesetaraan manusia berarti semua individu memiliki martabat dan hak yang sama. Hak asasi manusia melekat pada semua manusia karena ia seorang manusia, pemberian langsung dari Pencipta. Dari hari-kehari, dari masa-kemasa, negara-negara di dunia semakin banyak yang menggunakan demokrasi sebagai tatanan kenegaraannya. Merujuk pada teori Gelombang Demokratisasi Ketiga yang dikemukakan oleh Samuel P. Huntington, ${ }^{5}$ revolusi yang sekarang sedang

\footnotetext{
4 Merphin Panjaitan. 2011. Gerakan Warganegara Menuju Demokrasi. Jakarta: Penerbit Restu Agung. Hal 13-43.

5 Samuel P. Huntington dalam bukunya Gelombang Demokratisasi Ketiga mengungkapkan tiga gelombang demokratisasi, yaitu:Gelombang demokratisasi pertama mencakup periode 1828-1926, berakar pada Revolusi Amerika dan Revolusi Perancis. Kemunculan lembaga-lembaga demokrasi nasional yang sesungguhnya merupakan fenomena abad ke-19,mencakup demokratisasi di Amerika Serikat, Kanada, Australia, Selandia Baru,Inggris, Perancis, Swiss dan beberapa negara kecil di Eropa.Gelombang demokratisasi kedua, periode tahun 1943-1962, antara lain demokratisasi di Jerman Barat, Italia, Jepang, Austria, Turki, Yunani, Uruguai, Brasilia, Argentina, Kolombia, Peru, Venezuela, dan Kosta Rika. Pada dasawarsa 1960an beberapa negara di atas kembali ke pemerintahan militer,
} 
terjadi di Tunisia, Mesir, Libya, Suriah, Yaman, Bahrain dan negara-negara di sekitarnya, saya pikir adalah awal dari demokratisasi gelombang keempat. Semakin banyak negara memilih demokrasi, karena demokrasi adalah tatanan kenegaraan yang paling sesuai dengan martabat manusia.

\section{Reformasi Memberi Terlalu Banyak Harapan}

Di era Orde Baru ketidakadilan terjadi hampir di semua bidang kehidupan, kemudian menyisakan kemiskinan yang luas, pengangguran yang terlalu banyak, dan keterbelakangan pendidikan. Ditambah dengan hutang negara yang sangat besar dan korupsi yang merajalela. Semua ini terjadi setelah berjutajuta barel minyak bumi dihisap dari perut bumi, bahan tambang digali, hutan digunduli, lingkungan hidup dirusak. Kebebasan warganegara dirampas habis dan warganegara yang kritis terhadap pemerintah dianggap musuh yang perlu ditindas. Orde baru juga menciptakan kemiskinan struktural, yaitu kemiskinan yang diakibatkan oleh struktur politik, ekonomi dan sosial yang mempersulit kaum miskin mendapat akses ke berbagai sumberdaya yang seharusnya adalah hak mereka. Didik J.Rachbini mengemukakan bahwa Pemerintah Orde Baru gagal menciptakan pemerataan, sehingga kesenjangan sosial merebak dimana-mana. Fokus perhatian ke bidang ekonomi dengan jargon "pertumbuhan akan menetes ke bawah" dan "tidak ada pemerataan tanpa pertumbuhan karena yang dibagi cuma kemiskinan" akhirnya hanya wacana. Pertumbuhan tercapai tetapi pemerataannya tidak kunjung terwujud. Ternyata mekanisme pasar di era Orde Baru sangat distortif dan sengaja dipakai oleh pengusaha besar bersama-sama penguasa untuk memetik keuntungan abnormal yang sebesar-besarnya. ${ }^{6}$

seperti:Brasilia dan Argentina, dan periode ini di sebut gelombang balik kedua. Gelombang demokratisasi ketiga,dimulai tahun 1974 dengan berakhirnya pemerintahan diktator Portugal, diikuti Yunani dan Spanyol. Dalam 15 tahun, demokratisasi terjadi pada sekitar 30 negara di Eropa, Asia dan Amerika Latin. Menurut Huntington ada lima perubahan yang berperan dalam demokratisasi gelombang ketiga, yaitu:(1) Banyak orang telah menerima nilai-nilai demokrasi, mengakibatkan legitimasi sistem otoriter melemah; (2) Pertumbuhan ekonomi global yang luar biasa pada tahun 1960 an,mengakibatkan meningkatnya standar hidup, taraf pendidikan dan kelas menengah kota yang sangat membesar di banyak negara; (3) Perubahan mencolok pada doktrin dan kegiatan Gereja Katolik dalam Konsili Vatican Kedua di tahun 1963-1965, serta transformasi gereja-gereja nasional dari posisi sebagai posisi sebagai pembela status quo menjadi penentang otoriterisme dan pendukung reformasi sosial, ekonomi dan politik;(4) Perubahan kebijakan dari luar negeri, termasuk sikap baru Masyarakat Eropa yang memperluas keanggotaannya pada akhir dasawarsa 1960, kebijakan Amerika Serikat ke arah promosi hak asasi manusia dan demokrasi di negara lain mulai tahun 1974, serta perubahan dramatis dari kebijakan Gorbachev pada akhir dasawarsa 1980; (5)Efek demonstrasi dari transisi awal demokratisasi gelombang ketiga yang diperkuat oleh sarana komunikasi internasional, dalam merangsang dan menyediakan model bagi perubahan rezim di negara-negara selanjutnya. Dari lima faktor pendorong demokratisasi gelombang ketiga ini,minimal tiga faktor yaitu:(1),(2) dan (3) terjadi di Timur Tengah sekarang ini, yang kemudian diikuti perubahan kebijakan politik Amerika Serikat, negara-negara anggota Uni Eropa dan Liga Arab yang kemudian mendukung reformasi.

${ }^{6}$ Didik J.Rachbini. 2001. Ekonomi di Era Transisi Demokrasi. Jakarta: Penerbit Ghalia Indonesia. Hal. 13, 21 dan 23. 
Orde baru adalah fenomena yang sangat menyakitkan hati rakyat, disertai dengan pembunuhan massal sekitar satu juta warganegara tidak bersalah, yang dicap terlibat PKI pada tahun 1965-1966, dipadati dengan ketidakadilan dan diakhiri dengan kondisi ekonomi yang sangat parah. Krisis ekonomi yang berlangsung sejak Juli 1997 menghapus hampir semua keberhasilan ekonomi orde baru. Pertumbuhan ekonomi Indonesia merosot tajam dari rata-rata 7\% setahun menjadi negatif $15 \%$ selama tahun 1998 . Nilai tukar rupiah merosot menjadi hanya sekitar 25\% dari nilai tahun 1997. Industri banyak yang tutup, perdagangan menjadi sepi, pariwisata merosot dan mengakibatkan banyak pengangguran, terutama di perkotaan.Warga miskin bertambah banyak, dengan kemiskinan yang semakin berat dan bahkan sebagian dari mereka kelaparan. Presiden Soeharto turun pada 21 Mei 1998, orde baru runtuh dan reformasi nasional dimulai.

Reformasi membawa banyak harapan, keran kebebasan dibuka, media massa berkembang pesat dan sangat berperan dalam kehidupan kemasyarakatan dan kenegaraan. Reformasi mendorong keberanian berpolitik dari seluruh lapisan masyarakat, dengan tuntutan berantas korupsi, kolusi dan nepotisme (KKN) sampai keakar-akarnya. Hak-hak politik warganegara dipulihkan, kebebasan pers dijamin, dan tahanan politik dibebaskan. Partai politik bertumbuh pesat, berkembang dan sangat berperan. Pemilihan Umum di Indonesia telah berlangsung selama 10 kali. Pemilihan Umum pertama dilaksanakan pada tahun 1955, yang kedua tahun 1971, yang kedelapan tahun 1999, yang kesembilan tahun 2004 dan yang kesepuluh pada tahun 2009. Umumnya dalam menyongsong setiap pemilihan umum, masyarakat berharap akan terjadi perbaikan kehidupan setelah terbentuk lembaga-lembaga negara hasil pemilu, karena akan terpilih penyelenggara negara sesuai dengan pilihan rakyat dengan agenda pemerintahan yang sesuai dengan kehendak rakyat. Tetapi pengalaman kita sering memperlihatkan hasil yang berbeda. Pemerintahan negara setelah Pemilihan Umum Tahun 1955 ternyata diikuti konflik politik yang kontra produktif. Pemilihan Umum selama orde baru, yaitu Pemilihan Umum kedua sampai ketujuh tidak demokratis,dan kemudian berakhir dalam krisis ekonomi. Pemilihan Umum 1999, 2004 dan 2009 adalah pemilihan umum yang demokratis, berlangsung bebas, adil, kompetitif dan berkala. Selain itu gubernur, bupati dan walikota sejak beberapa tahun terakhir ini juga telah dipilih secara langsung dalam pemilihan umum kepala daerah di wilayahnya masing-masing.

Pemilihan umum yang demokratis ini adalah suatu kemajuan besar dalam kehidupan kemasyarakatan dan kenegaraan Indonesia. Reformasi telah berlangsung lebih dari 10 tahun, dan telah dicapai beberapa kemajuan politik. Tetapi di bidang ekonomi, sosial, penegakan hukum dan pemberantasan korupsi, serta kebebasan beragama dan berkepercayaan belum pulih. Pengangguran dan penduduk miskin tetap banyak, konflik kekerasan antar berbagai kelompok masyarakat masih sering terjadi dengan korban jiwa dan harta yang besar. Intoleransi atas dasar agama/kepercayaan meningkat, teror massa berkembang, dan kerusakan lingkungan hidup masih terus terjadi. Korupsi tetap merajalela bahkan meluas sampai keseluruh nusantara, melibatkan pejabat negara di lembaga 
eksekutif, legislatif dan yudikatif. Komisi Pemberantasan Korupsi telah bekerja dan sempat memberikan harapan, tetapi korupsi terus meluas dan kemudian menimbulkan frustasi dikalangan masyarakat luas.

Ketidakadilan terhadap warga miskin tetap banyak terjadi, hingga timbul kesan dikalangan masyarakat luas bahwa keadilan tidak tersedia bagi warga miskin. Keadilan itu dibuat mahal dan oleh karena itu hanya tersedia bagi warga kaya. Ketidakadilan ini, yang masih terus berlangsung dengan sangat mencolok adalah kejahatan negara terhadap rakyat. Kegagalan mengatasi krisis ekonomi, ditambah dengan berbagai permasalahan bangsa lainnya, membuat frustasi yang mendalam di tengah-tengah masyarakat. Banyak warganegara kemudian kehilangan kepercayaan kepada Pemerintah. Kondisi ini akan menghambat demokratisasi dan kemajuan di berbagai bidang kehidupan. Reformasi memberi terlalu banyak harapan, tetapi terlalu sedikit yang terwujud.

Hatta dalam tulisannya berjudul "Arti Kedaulatan Rakyat bagi Pergerakan Sekarang" sejak jauh hari mengingatkan tentang perlunya rakyat menyadari cita-cita Kedaulatan Rakyat. Ia mengingatkan,

Bahwa Indonesia lambat laun mesti merdeka,.....Itu sudah Hukum Riwayat! Indonesia Merdeka bukan perkara dapat atau tidak, hanya perkara waktu saja...Dari mulai sekarang cita-cita Kedaulatan Rakyat harus ditanam dalam hati rakyat! Kalau tidak rakyat tidak akan insyaf akan harga dirinya, sehingga ia mudah tunduk ke bawah kekuasaan apa dan siapa juga. Dan kalau Indonesia sampai merdeka, ia akan tinggal tertindis, ... Dan dalam Indonesia Merdeka yang seperti itu tidak berarti rakyat merdeka! ........ Negeri hanya dapat maju kalau rakyat turut menimbang mana yang baik dan mana yang buruk bagi dia. Pendeknya, kalau rakyat tahu memerintah diri sendiri, tahu mempunyai kemauan dan melakukan kemauan itu dengan rasa tanggung jawab penuh. ${ }^{7}$

Pernyataan ini, yang disampaikan Hatta puluhan tahun yang lalu, mengingatkan kita tentang perlunya pendidikan kewarganegaraan bagi seluruh warganegara, agar rakyat ikut aktif dalam proses penyelenggaraan negara, termasuk rakyat kecil yang sering dipinggirkan dan ditindas. Masyarakat miskin sering diperlakukan sebagai penggembira sekaligus pelengkap penderita. Pada waktu kampanye pemilihan umum mereka dirayu dan dihormati agar bersedia memberikan suaranya,tetapi beberapa bulan kemudian mereka digusur tanpa dialog sebelumnya. Kenyataan di atas memaksa kita untuk kritis terhadap negara.

Kekuasaan negara itu sangat besar pengaruhnya terhadap kehidupan umat manusia, tetapi jangan lupa, kekuasaan cenderung disalah gunakan. Dictum Lord Acton berbunyi: Power tends to corrupt, absolute power corrupt absolutely. Penyelenggara negara adalah manusia biasa, yang sama seperti manusia lainnya mempunyai kebutuhan pribadi yang tidak terbatas. Mereka tentu mengetahui tugas dan tanggung-jawabnya, tetapi kalau tidak diawasi, mereka cepat lupa dan

\footnotetext{
${ }^{7}$ Mohammad Hatta. 1976. “Arti Kedaulatan Rakyat bagi Pergerakan Sekarang”. Hal 118.
} 
kembali memperkaya diri dengan menyalahgunakan kekuasaanya untuk memenuhi kepentingan pribadi yang tidak terbatas itu. Oleh karena itu rakyat harus selalu mengendalikan negara, karena kalau negara lepas dari kendali rakyat, negara yang besar kekuasaannya itu akan disalahgunakan untuk kepentingan pejabat negara. Negara adalah alat milik rakyat untuk kebaikan bersama rakyat seluruhnya, dan negara yang seperti itu adalah negara demokrasi, yang proses penyelenggaraannya harus berada dalam kendali rakyat. Pertanyaan selanjutnya adalah bagaimana rakyat memperkuat kendalinya terhadap negara.

\section{Interaksi Politik Negara-Masyarakat}

Dalam negara demokrasi, terjadi interaksi politik negara-masyarakat. Dalam interaksi tersebut terjadi proses sebagai berikut. Negara membuat keputusan dan menjalankannya. Negara mendengarkan aspirasi masyarakat.dan menggunakan aspirasi tersebut sebagai bahan masukan dalam pengambilan keputusan kenegaraan. Berbagai kelompok masyarakat yang kepentingannya tidak selalu sama menawarkan kepentingannya untuk dijadikan kebijakan negara. Aktifitas politik ini dikenal sebagai partisipasi politik masyarakat. Dalam interaksi ini kedua belah pihak sama-sama mengunakan kekuasaan politik. Negara mendapatkan kekuasaan dari rakyat untuk digunakan melayani dan mengatur masyarakat dan warganegara mendapat kekuasaan politik "satu orang satu suara".

Interaksi politik negara-masyarakat seharusnya berlangsung damai, dialogal, adil, seimbang dan saling mempercayai. Interaksi politik ini akan membuat negara selalu berada dalam kendali rakyat, yang akan membawa kestabilan negara dan kemajuan seluruh lapisan masyarakat. Masyarakat berpengaruh efektif dalam penyelenggaraan negara, dan negara dapat melayani dan mengatur masyarakat secara optimal. Masyarakat menjadi lebih dinamis, kreativitas invidu berkembang, hubungan antar kelompok masyarakat harmonis dan negara menjadi lebih demokratis, adil dan maju.

Interaksi politik negara-masyarakat seperti di atas membutuhkan kondisi sebagai berikut.

Pertama, tersedia pemilihan umum yang bebas, adil, kompetitif dan berkala. Dalam negara demokrasi, pemerintahan berlangsung atas persetujuan rakyat. Penyelenggara negara, khususnya pimpinan eksekutif dan anggota legislatif dipilih langsung oleh rakyat dalam pemilihan umum. Legitimasi pemerintahan terutama bukan pada keahlian dan kepintaran mereka, tetapi pada persetujuan dan pilihan rakyat. Dalam negara demokrasi, rakyat paling berhak dan paling mengetahui tentang siapa yang layak menjadi penyelenggara negara. Oleh karena itu suatu negara dapat dikatakan demokrasi, kalau di negara tersebut terdapat pemilihan umum yang bebas, adil kompetitif dan berkala. Pemilihan pejabat negara secara langsung oleh rakyat yang telah berlangsung berulang-ulang akan mengkondisikan setiap pejabat negara menjadi pelayan rakyat. Semakin 
banyak pejabat negara yang dipilih oleh rakyat, semakin banyak pejabat negara yang melayani rakyat, dan hasilnya kebijakan negara semakin sesuai dengan kehendak rakyat. Pejabat negara dipilih oleh rakyat dan mereka harus bertanggung jawab atas kerja mereka, terutama dalam kaitan dengan pemenuhan janji dan komitmen yang diberikannya pada waktu kampanye. Siapapun yang menjadi pejabat negara, mereka harus memperjuangkan kehendak rakyat. Kesempatan untuk menduduki jabatan-jabatan negara, ukurannya bukan asalusul, ras, suku, agama, kedudukan, atau kekayaan, tetapi ditentukan oleh pilihan rakyat.

Kesetaraan manusia berarti tidak ada orang atau kelompok orang yang karena keturunan, asal-usul, suku, ras, agama, golongan dan jenis kelamin lebih berhak untuk memerintah orang lain. Dalam kesetaraan manusia, tetap ada pemimpin yang akan memerintah, tetapi mereka dipilih oleh yang diperintah dari antara mereka sendiri. Suku, ras, asal-usul, keturunan, agama, golongan, gelar, pangkat, jabatan, kekayaan, jenis kelamin dan perbedaan-perbedaan lainnya tidak membuat derajat manusia berbeda, karena kesetaraan melekat pada diri manusia dan tetap ada padanya selama ia masih manusia. Pemilihan Umum mempunyai beberapa fungsi yang tidak dapat dipisahkan satu dengan yang lain: (1). Sebagai sarana legitimasi politik. Fungsi legitimasi ini menjadi kebutuhan pemerintah. Melalui pemilihan umum, keabsahan pemerintah yang sedang berkuasa ditegakkan, begitu pula kebijakan dan program yang dihasilkannya. (2). Fungsi perwakilan politik. Fungsi ini terutama menjadi kebutuhan rakyat, sebagai mekanisme demokratis bagi rakyat untuk menentukan wakil-wakil yang dapat dipercaya untuk duduk dalam pemerintahan maupun dalam lembaga legislatif. Tidak ada demokrasi tanpa representasi. (3). Sebagai mekanisme sirkulasi elite politik. Keterkaitan pemilihan umum dengan sirkulasi elite politik didasarkan pada asumsi bahwa elite politik berasal dan bertugas mewakili rakyat. Pemilihan umum menjadi sarana bagi warganegara untuk mencapai posisi elite politik. (4). Sebagai sarana pendidikan politik rakyat. Pemilihan umum merupakan salah satu bentuk pendidikan politik bagi rakyatyang bersifat langsung, terbuka dan massal, yang diharapkan bisa mencerdaskan masyarakat tentang demokrasi. ${ }^{8}$

Sistem pemilihan umum di Indonesia memberikan kekuasaan terlalu besar kepada partai politik dan sekaligus mengurangi hak warganegara. Pencalonan anggota DPR dan DPRD, serta pencalonan Presiden yang seharusnya adalah hak warganegara, hanya diperbolehkan melalui partai politik. Partai politik yang seharusnya menjadi alat politik warganegara telah "bermetamorfose menjadi pemilik negara", dan digunakan mengurangi hak politik warganegara.

Di dalam negara demokrasi yang memiliki hak untuk mengajukan calon, dipilih dan memilih adalah warganegara, bukan partai politik. Berdasarkan pemikiran di atas seharusnya calon independen (calon perorangan) untuk jabatan

${ }^{8}$ Lih. Syamsuddin Haris (ed). 1998. Menggugat Pemilihan Umum Orde Baru. Jakarta: Yayasan Obor Indonesia. Hal. 7-10. 
Presiden, anggota DPR, dan anggota DPRD diperbolehkan. Warganegara dapat mengusulkan calon pejabat negara melalui partai politik atau langsung dicalonkan oleh sekelompok warganegara. Untuk mewujudkan pemikiran ini, kedalam Undang-Undang Dasar Negara Republik Indonesia Tahun 1945 perlu ditambahkan lagi hak warganegara yaitu: hak mengusulkan calon-calon penyelenggara negara yang akan dipilih langsung oleh rakyat, seperti calon presiden, calon anggota DPR, calon anggota DPD, calon anggota DPRD, calon gubernur, calon bupati dan calon walikota, serta hak memilih dan dipilih menjadi penyelenggara negara. Dan hak partai politik mengusulkan pasangan calon Presiden dan Wakil Presiden yang dimuat dalam Undang-Undang Dasar Negara Republik Indonesia Tahun 1945, pasal 6A ayat(2) yang berbunyi: Pasangan calon Presiden dan Wakil Presiden diusulkan oleh partai politik atau gabungan partai politik peserta pemilihan umum sebelum pelaksanaan pemilihan umum,dikeluarkan dari Undang-Undang Dasar. ${ }^{9}$ Demikian pula dengan pasal 22E ayat (3) yang berbunyi: Peserta pemilihan umum untuk memilih anggota Dewan Perwakilan Rakyat dan anggota Dewan Perwakilan Rakyat Daerah adalah partai politik dan ayat (4) yang berbunyi:Peserta pemilihan umum untuk memilih anggota Dewan Perwakilan Daerah adalah perorangan.

Peserta pemilihan umum dalam negara demokrasi seharusnya adalah warganegara yang memenuhi persyaratan seperti yang diatur dalam undangundang. Oleh karena itu, yang dipilih dalam pemilihan anggota legislatif sama dengan pemilihan pimpinan eksekutif, yaitu warganegara yang menjadi calon bukan memilih partai politik. Sehubungan dengan itu pemilihan anggota legislatif akan lebih baik menggunakan sistem distrik dengan banyak anggota(multi member district system), dengan kursi dalam setiap distrik pemilihan antara $3-8$. Pemilihan Umum dengan sistem ini akan memudahkan pemilih menjatuhkan pilihan, karena hanya memilih nama calon. Penghitungan suara juga lebih mudah karena hanya menghitung suara perolehan calon, karena tidak ada suara perolehan partai. Saya usulkan Pemilihan Umum dibagi menjadi dua bagian. Pemilihan Umum Nasional untuk memilih anggota DPR, DPD, dan Presiden dan Pemilihan Umum Daerah untuk memilih anggota DPRD dan kepala daerah.Pemilihan Umum Daerah dilaksanakan pada waktu yang berbeda dengan Pemilihan Umum Nasional,agar agenda pembangunan daerah tidak tertutup oleh agenda nasional. Masa jabatan anggota Dewan Perwakilan Rakyat Daerah (DPRD) dan kepala daerah diubah menjadi empat tahun, lebih pendek dari masa jabatan penyelenggara negara di tingkat nasional. Pemilihan Umum Daerah sebaiknya dilaksanakan serempak, agar tidak menyita terlalu banyak waktu, tenaga dan perhatian.

\footnotetext{
9 Pasal 6A ayat(2) ini masuk ke dalam Undang-Undang Dasar Negara Republik Indonesia Tahun 1945 pada Perubahan Ketiga, yang dilaksanakan tahun 2001. Masuknya partai politik ke dalam Undang- Undang Dasar adalah suatu keanehan, karena partai politik bukan lembaga negara.Kalau tidak waspada, dikhawatirkan di kemudian hari nanti banyak organisasi masyarakat masuk dalam Undang-Undang Dasar.
} 
Dalam upaya meningkatkan kendali rakyat terhadap negara,perlu diingat, bahwa salah satu fungsi pemilihan umum adalah untuk menjatuhkan sanksi politik kepada politisi yang gagal, dengan tidak memilihnya kembali. Pemilih mungkin tidak peduli atau barangkali tidak sadar tentang perlunya menjatuhkan sanksi politik. Sikap seperti ini akan menguntungkan para politisi, karena dengan demikian mereka tidak perlu memberikan pertanggung jawaban politik kepada rakyat, tetapi akan merugikan seluruh rakyat Indonesia secara bersama-sama, karena akhirnya Indonesia menjadi tempat bercokol politisi-politisi gagal.Suatu negara demokrasi hanya dapat maju,tumbuh dan berkembang, kalau rakyat si pemilik negara bersedia dan mampu menjatuhkan sanksi politik.

Kedua, kekuasaan negara dibatasi. Manusia hadir lebih dahulu dari negara, dan bahkan manusialah yang mendirikan negara, oleh karena negara dibutuhkan untuk mewujudkan kehidupan bersama yang lebih baik. Negara didirikan untuk kepentingan rakyat, dan oleh karena itu kekuasaan negara harus dibatasi agar rakyat dapat mengendalikannya. Kekuasaan negara juga harus dibatasi agar tersedia ruang gerak masyarakat untuk mengembangkan dirinya, dan sebagai jaminan bagi pemenuhan hak asasi manusia. Manusia, baik sebagai individu maupun sebagai masyarakat membutuhkan kebebasan, agar mereka dapat hidup wajar, sehat dan berkembang. Hak asasi manusia harus didapat oleh setiap individu. Kekuasaan Negara juga harus dibatasi karena masyarakat mempunyai kemampuan untuk melaksanakan berbagai fungsi kemasyarakatan, yang akan lebih baik kalau dilaksanakan oleh masyarakat sendiri, tanpa intervensi dari negara. Negara dan masyarakat harus mengetahui fungsi dari kedua pihak,dan tidak mengambil alih fungsi pihak lain. Negara mempunyai fungsi tertentu dengan kekuasaan yang terbatas, demikian pula masyarakat mempunyai fungsi kemasyarakatan. Negara tidak boleh mengintervensi semua kegiatan masyarakat, dan masyarakat harus patuh pada keputusan negara. Kekuasaan negara harus dibatasi oleh karena negara adalah alat yang dibentuk oleh rakyat. Kekuasaan negara tidak boleh tidak terbatas agar rakyat dapat mengendalikannya. Negara dengan kekuasaan yang tidak terbatas akan mengambil alih semua fungsi-fungsi masyarakat.

Rakyat secara bersama-sama menjadi pemilik negara dan secara bersama-sama pula mengendalikan negara. Negara dibentuk untuk membantu masyarakat dalam menjalankan fungsi-fungsi tertentu, dan banyak fungsi-fungsi masyarakat yang akan lebih baik kalau dijalankan sendiri oleh masyarakat,negara tidak perlu melaksanakannya. Negara hanya melakukan fungsi yang tidak dapat dilakukan sendiri dengan baik oleh masyarakat.Negara hanya melengkapi, bukan menggantikan masyarakat. Negara membantu individu dan masyarakat, dalam berbagai fungsi yang tidak dapat dikerjakan sendiri dengan baik oleh mereka. Negara subsidier terhadap masyarakat. Dari pemikiran ini terbentuklah salah satu prinsip negara demokrasi, yaitu prinsip subsidiaritas: negara berfungsi membantu masyarakat, dan berbagai kegiatan yang dapat dilaksanakan sendiri dengan baik oleh masyarakat, negara tidak perlu melakukannya. Kata "subsidiaritas" berasal 
dari kata Latin "subsidium" yang berarti "bantuan, sokongan".10 Kekuasaan negara dibatasi oleh motivasi keberadaannya, yaitu melayani rakyat seluruhnya. Negara tidak boleh menggunakan kekuasaannya untuk mencampuri segala bidang kehidupan masyarakat. Negara tidak mempunyai legitimasi untuk mengurus segala-galanya.Negara yang mengurus segalanya adalah negara totaliter, yang akan merampas kebebasan warganegara. Kekuasaan negara dibutuhkan, antara lain untuk memelihara keamanan dan ketertiban masyarakat serta menegakkan keadilan. Tetapi kalau kekuasaan negara menjadi tidak terbatas, sejarah memperlihatkan,negara tersebut akan berubah menjadi "monster" yang akan menindas rakyat sipemilik negara.

Ketiga, kekuasaan negara didistribusikan keberbagai lembaga negara secara seimbang dan saling mencheks. Demokrasi adalah sistem politik,yang pada awalnya antitesis dari pemusatan kekuasaan di tangan raja atau di tangan segelintir penguasa,yang memonopoli penggunaan kekuasaan negara untuk kepentingan sendiri tanpa menghiraukan rakyat. Memonopoli kekuasaan juga berarti memonopoli kebenaran. Karena merupakan antitesis dari pemusatan kekuasaan, maka demokrasi menolak pemusatan kekuasaan pada satu lembaga negara, dan membaginya kedalam tiga cabang kekuasaan negara yang seimbang dan saling checks.Itulah demokrasi "trias politica" dari Montesquieu, membagi kekuasaan ke dalam tiga lembaga politik,yaitu legislatif, eksekutif dan yudikatif. Dengan trias politica masyarakat dapat menggunakan lembaga yang satu menghadapi yang lain, dan itulah cara masyarakat mempengaruhi proses penyelenggaraan negara. Struktur dan prosedur kenegaraan dibuat seperti itu agar responsif terhadap kepentingan rakyat, stabil dan kokoh. Kekuasaan negara dibatasi dan didistribusikan keberbagai lembaga negara. Di tingkat nasional, secara horisontal kekuasaan negara dibagi-bagikan ke dalam lembaga legislatif, eksekutif, dan yudikatif. Setiap lembaga negara ini mendapatkan kekuasaan yang berimbang dan dapat saling men check. (prinsip checks and balances).

Dengan demikian tidak ada satu lembaga negara pun yang dapat mendominasi lembaga negara lainnya, hingga rakyat dapat menggunakan berbagai lembaga negara ini demi peningkatan keamanan dan kesejahteraannya. Selain itu prinsip checks and balances untuk mencegah penyalah gunaan kekuasaan negara. Secara vertikal kekuasaan negara di bagi kepada pemerintahan nasional dan pemerintahan daerah. Pemerintahan daerah adalah mitra kerja lebih rendah dari pemerintahan nasional dalam menjalankan fungsi-fungsi negara.Pemerintahan nasional dengan pemerintahan daerah akan dapat berfungsi optimal kalau terjalin hubungan dialogal yang tulus dan saling mempercayai diantara mereka, karena mereka secara bersama-sama melayani rakyat di wilayah yang sama. Kesombongan pemerintahan nasional terhadap pemerintahan daerah, atau sebaliknya akan kontra-produktif. Demokrasi adalah penyelenggaraan negara oleh semua untuk kepentingan semua,dengan dialog dan pengambilan suara.

${ }^{10}$ Lihat Frans Magnis Suseno.1992. Etika Politik. Jakarta: Penerbit PT Gramedia. Hal. 306-307. 
Keempat, partisipasi politik masyarakat harus efektif. Partisipasi politik adalah berbagai bentuk kegiatan warganegara biasa yang bertujuan untuk memilih atau menjatuhkan pejabat negara,mempengaruhi pembuatan kebijakan negara, dan mengawasi kerja pejabat negara. Partisipasi politik bisa bersifat individual atau kolektif, terorganisi atau spontan, berkelanjutan atau sporadis, secara damai atau dengan kekerasan, legal atau ilegal, efektif atau tidak efektif, mendapat dukungan masyarakat luas atau tidak. Partisipasi politik dilaksanakan dalam berbagai bentuk,antara lain: pemberian suara dalam pemilihan umum, diskusi politik, kegiatan kampanye, membentuk dan bergabung dengan kelompok kepentingan, komunikasi dengan pejabat negara, pengajuan petisi, demonstrasi, mogok, dan pembangkangan sipil. Prinsip pemerintahan semua untuk semua dalam demokrasi perwakilan hanya akan terwujud, kalau partisipasi politik masyarakat berlangsung luas, mendalam dan berpengaruh kuat dalam kehidupan kenegaraan. Demokrasi perwakilan tanpa partisipasi politik yang efektif hanya akan menghasilkan oligarki. Partisipasi politik yang luas adalah apabila partisipasi politik datang dari semua lapisan masyarakat. Warganegara dari semua lapisan masyarakat, kaya atau miskin, mayoritas atau minoritas, pendidikan rendah atau tinggi, beragama atau tidak beragama, terkenal atau tidak terkenal, penduduk kota atau desa, buruh atau majikan, pelajar atau guru, mahasiswa atau dosen, dan seterusnya, sadar akan haknya dan ikut berpartisipasi politik, tanpa takut terhadap ancaman pihak manapun. Masyarakat harus kritis terhadap negara, karena negara adalah pelembagaan kekuasaan, dan sekecil apapun, kekuasaan cenderung disalahgunakan.

Kelima, dalam berinteraksi dengan masyarakat, juga berlangsung interaksi yang seimbang dan demokratis antar berbagai lembaga negara. Demikian pula sebaliknya, dalam berinteraksi dengan negara terjadi interaksi antar berbagai kelompok masyarakat yang damai, bebas dan toleran.

\section{Otonomi Daerah}

Pemberian sebagian dari kekuasaan negara kepada pemerintahan daerah dimaksudkan untuk mendekatkan kekuasaan negara kepada rakyat, dan dikenal sebagai otonomi daerah. Semakin dekat kekuasaan negara kepada rakyat, semakin mudah rakyat mengendalikan negara melalui peningkatan partisipasi politik masyarakat dalam proses penyelenggaraan negara, mulai dari pemilihan penyelenggara negara sampai dengan proses penetapan kebijakan publik, pelaksanaan dan evaluasinya.

Otonomi daerah adalah gabungan dari desentralisasi dan debirokratisasi. Masyarakat akan lebih mudah mempengaruhi pembuatan kebijakan publik di daerah mereka masing-masing, daripada harus datang ke Jakarta untuk mempengaruhi pembuatan kebijakan publik yang tersentralisasi, seperti di era Orde Baru. Republik Indonesia dengan luas wilayah sekitar 5 juta km2 dan penduduk sekitar 240 juta jiwa, akan sulit dikendalikan rakyat, kalau segala 
sesuatu tentang negara harus diputuskan di Jakarta. Masyarakat kita beraneka ragam: budaya, pendidikan, pekerjaan, pendapatan, bahasa, agama dan masih banyak perbedaan lainnya. Hidup di wilayah yang juga tidak sama, daerah perkotaan, pedesaan, daratan, kepulauan, hutan, lahan gambut, tanah kritis, dan lain sebagainya. Selain itu, sesuatu yang sering kita lupakan dari otonomi daerah adalah bahwa otonomi daerah juga berarti, rakyat memberikan kepercayaan baik kepada pemerintahan nasional maupun pemerintahan daerah.

Rakyat memberikan kepercayaan kepada Pemerintahan Nasional, pemerintahan provinsi, pemerintahan kabupaten, pemerintahan kota dan seharusnya juga kepada pemerintahan desa/kelurahan, dengan tugas menjalankan kekuasaan negara yang dipercayakan kepada mereka untuk melayani rakyat seluruhnya. Oleh karena itu semua lembaga pemerintahan pusat dan daerah harus terbuka dan bertanggung jawab kepada rakyat.

Hatta dalam tulisannya berjudul Kearah Indonesia Merdeka mengungkapkan sebagai berikut

Menurut dasar demokrasi itu, hak rakyat untuk menentukan nasibnya tidak saja ada pada pucuk pemerintahan negeri,melainkan juga pada tiap tempat,di kota,di desa dan di daerah.Tiap-tiap golongan persekutuan itu mempunyai Badan Perwakilan sendiri. ${ }^{11}$

Keberhasilan pelaksanaan otonomi daerah akan menghasilkan berbagai kemajuan, antara lain, pertama, pemberdayaan masyarakat di daerah. Dengan diberlakukannya otonomi daerah, masyarakat di daerah menyadari bahwa pengaruh mereka dalam kehidupan kenegaraan di daerah mereka masing-masing cukup besar dan bermanfaat.Masyarakat dapat mempengaruhi pembuatan Perda, penyusunan APBD, dan kebijakan publik lainnya. Masyarakat juga menyadari, bahwa siapa yang akan menjadi anggota DPRD dan pimpinan eksekutif di daerahnya adalah hasil pilihan rakyat melalui pemilihan umum. Kesadaran masyarakat akan prosedur kenegaraan di atas membuat masyarakat berminat belajar politik dan meningkatkan partisipasi politiknya, yang akan membuat masyarakat semakin berdaya. Kemajuan suatu negara demokrasi membutuhkan interaksi antara negara yang kokoh dan masyarakat yang berdaya. Kedua, Optimalisasi pelayanan publik. Fungsi negara antara lain melindungi kehidupan masyarakat, meningkatkan kesejahteraan, dan menegakkan keadilan. Fungsi ini dijalankan dengan mengadakan pengaturan (regulasi) dan pelayanan publik. Pengaturan dan pelayanan publik untuk seluruh wilayah negara yang cukup luas seperti Republik Indonesia tidak dapat semuanya dilaksanakan oleh Pemerintahan Nasional. Oleh karena itu, untuk mengoptimalkan pelayanan publik, maka banyak kebijakan publik yang sebaiknya diputuskan di daerah, oleh pemerintahan daerah bersama-sama dengan masyarakat setempat. Ketiga, Percepatan dan pemerataan pembangunan daerah. Dengan dilaksanakannya otonomi daerah maka kekuasaan negara tersebar keseluruh wilayah negara. Pemerintahan daerah bersama-sama

${ }^{11}$ Mohammad Hatta. Ibid., hal.103. 
dengan masyarakat dapat menggunakan kekuasaan dan dana yang mereka dapat untuk memajukan pembangunan di daerah mereka masing-masing. Semua daerah akan maju seperti apa yang mereka butuhkan dan Pemerintahan Nasional tinggal memberi dukungan pada bidang-bidang tertentu saja. Dan kalau ada daerah yang tertinggal, mereka tidak perlu menyalahkan pihak lain, tetapi segera introspeksi, belajar lebih banyak, terutama dari daerah yang lebih maju, dan tidak perlu berontak untuk memisahkan diri. Dalam kondisi tertinggal seperti ini, biasanya masyarakat akan memilih anggota DPRD dan pimpinan eksekutif yang baru. Masyarakat akan berpartisipasi optimal untuk kemajuan daerahnya, tetapi kalau penyelenggara negara di daerahnya gagal, masyarakat akan "menghukum" mereka. Otonomi daerah memberikan kesempatan kepada semua daerah otonom untuk maju dan berkembang sesuai dengan kebutuhan masyarakat setempat sebagai bagian dari seluruh rakyat Indonesia. Keempat, Rekrutmen politik lokal: otonomi daerah memberikan kesempatan seluas-luasnya kepada warganegara di masing-masing daerah untuk berkompetisi menjadi penyelenggara negara di daerahnya masing-masing. Anggota DPRD, bupati, walikota, gubernur sebagian besar akan berasal dari daerahnya masing-masing, karena masyarakat setempat yang akan mencalonkan dan memilih mereka.Proses pencalonan dan pemilihan anggota legislatif dan pimpinan eksekutif di daerah seperti ini akan menjadi lahan yang subur bagi tumbuh berkembangnya politisi daerah yang kemudian dapat meningkat menjadi politisi nasional. Demokrasi bertumbuh dari bawah, yaitu dari masyarakat luas, bukan turun dari ibukota negara, karena yang lebih berkepentingan dengan demokrasi adalah masyarakat,bukan para petinggi negara.

\section{Penambahan Daerah Otonom}

Demokrasi adalah tatanan kenegaraan dengan rakyat sebagai pemegang kendali dalam penyelengaraan negara. Sekali demokrasi dimulai, demokrasi itu sendiri akan bergerak mempertahankan kelangsungannya berkonsolidasi terus untuk memantapkan diri. Demokrasi yang telah dimulai kembali pada tahun 1998 akan terus berlanjut, semakin dalam dan meluas, sampai penyelenggaraan kehidupan kenegaraan, baik di aras nasional maupun daerah berada dalam kendali rakyat. Otonomi daerah adalah bagian dari demokrasi, untuk memperkuat kendali rakyat dalam penyelenggaraan pemerintahan daerah, yang selanjutnya akan memperkuat kendali rakyat dalam penyelengaraan negara.

Tetapi kita masih menghadapi kendala yang besar. Sampai dengan tahun 2009, jumlah daerah otonom di Indonesia masih terlalu sedikit, yaitu 33 provinsi, 398 kabupaten dan 93 kota, sehingga masing-masing daerah otonom masih terlalu luas dan atau terlalu banyak penduduknya. Kondisi ini akan menyulitkan masyarakat setempat dalam mempengaruhi proses pemerintahan daerahnya, baik pada waktu pemilihan anggota DPRD dan pimpinan eksekutif, dan terutama pada waktu pembuatan kebijakan publik dan pengawasannya. 
Berdasarkan pemikiran di atas, kita mempunyai agenda yang berat, yaitu menambah jumlah daerah otonom: provinsi, kabupaten dan kota, dengan lebih cepat secara serempak di seluruh Indonesia. Optimalisasi pelaksanaan otonomi daerah membutuhkan kondisi yang kondusif bagi komunikasi dialogal antara masyarakat dengan pemerintahan daerah, yang tentunya akan lebih mudah tercapai apabila daerah otonom tidak terlalu luas dan atau terlalu padat penduduknya.Christian D. Natividad seorang anggota Municipal Councilor di Municipality (kabupaten) Malolos, provinsi Bulacan, Filipina, menyatakan bahwa dalam suatu municipality yang penduduknya tidak terlalu banyak seperti Malolos (penduduk sekitar 170.000 jiwa) akan memudahkan dialog antara pemerintah lokal dengan masyarakat. Penduduk yang terlalu banyak akan memaksa pemerintahan lokal menambah birokrasi, yang akan menghambat hubungan antara pejabat pemerintahan lokal dengan masyarakat. ${ }^{12}$ Pemikiran ini mendasari terbentuknya banyak daerah otonom di Filipina, yang dengan luas daratan sekitar $300.000 \mathrm{~km}^{2}$ dan pada tanggal 1 Mei 2000 mempunyai penduduk 75,3 juta orang, memiliki 78 provinsi, 83 city, 1525 municipality (kabupaten) dan 41940 barangay (desa/kelurahan). Di sini terdapat sekitar 10 propinsi dengan penduduk kurang dari 200.000.

Thailand dengan luas wilayah $514.000 \mathrm{~km}^{2}$ pada tahun 2005 penduduk sekitar 65,4 juta jiwa, terbagi ke dalam 75 provinsi dan daerah khusus Bangkok, dan 795 distrik. ${ }^{6}$ Dan salah satu provinsi di Thailand, yaitu provinsi Phuket dengan luas wilayah $543 \mathrm{~km}^{2}$ dan penduduk sekitar 288.000 jiwa. Provinsi ini cukup maju dan banyak dikunjungi turis asing.7 Republik Indonesia dengan luas wilayah sekitar 5 juta km2, pada tahun 2010 penduduk sekitar 240 juta jiwa, hanya mempunyai 33 provinsi, 398 kabupaten, dan 93 kota. Sejak dari tahun 1999 sampai dengan tahun 2009, penambahan daerah otonom hanya 205 daerah, terdiri dari 7 provinsi yaitu: Kep.Riau, Bangka Belitung, Banten, Gorontalo, Sulawesi Barat, Maluku Utara, dan Irian Jaya Barat, dan 164 kabupaten dan 34 kota. Penambahan daerah otonom di Indonesia sangat lambat, dan keterlambatan ini menghambat proses pemantapan demokrasi, yaitu memperkuat kendali rakyat terhadap negara.

Banyaknya daerah otonom di suatu wilayah tergantung dari tiga faktor utama, yaitu: jumlah penduduk, luas wilayah, dan keterpencilan wilayah. Semakin banyak penduduk dalam satu wilayah, semakin banyak dibutuhkan daerah otonom, demikian pula dengan luas wilayah. Semakin terpencil suatu pulau atau wilayah semakin diperlukan daerah otonom. Dengan menggunakan tiga faktor di atas saya mengusulkan penambahan daerah otonom dapat dilaksanakan dengan lebih cepat sehingga sampai dengan tahun 2020 Republik Indonesia telah memiliki sekitar 100 provinsi dan 2000 kabupaten/kota. Penambahan daerah otonom secara besar-besaran ini harus disertai dengan pengurangan jumlah pejabat negara di masing-masing daerah otonom. Anggota DPRD provinsi dikurangi menjadi 12-20 orang, anggota DPRD kabupaten dikurangi menjadi 8-10 orang, dan anggota DPRD kota dikurangi menjadi 8-12 orang. Kecamatan dihapus, karena dapat

\footnotetext{
${ }^{12}$ Merphin Panjaitan. Ibid., hal 79.
} 
menghambat interaksi antara pejabat negara di kabupaten/kota dengan masyarakat setempat dan kepada pemerintahan desa/kelurahan diberikan otonomi daerah.

Jumlah pegawai daerah dimasing-masing daerah otonom juga harus dibatasi, demikian pula penggunaan Dana Alokasi Umum untuk gaji. Semua ketentuan diatas dimuat dalam Undang-Undang tentang Pemerintahan Daerah.

Banyak pengamat otonomi daerah dan politisi menyatakan dalam upaya pembentukan suatu daerah otonom perlu dipertimbangkan PAD, perekonomian dan potensi sumber daya alam setempat. Saya ingin katakan bahwa faktor-faktor di atas justru berakibat sebaliknya. Otonomi daerah adalah untuk memperkuat pengaruh masyarakat dalam proses pemerintahan daerah dalam kerangka mempercepat peningkatan kesejahteraan masyarakat setempat. Semakin miskin suatu daerah, semakin dibutuhkan kekuasaan politik yang lebih besar untuk membantu peningkatan pendapatan dan kesejahteraannya.

Argumentasi lain, adalah argumentasi yang sulit dibantah, karena keberadaan daerah otonom baru untuk mendekatkan kekuasaan negara kepada masyarakat adalah konsekwensi dari demokrasi, dalam upaya memperkuat kendali rakyat tyerhadap negara.

Saya mengusulkan penambahan daerah otonom dengan rincian sebagai berikut: Pulau Sumatera dengan luas $447.000 \mathrm{~km}^{2}$ pada tahun 2010 penduduk sekitar 51 juta jiwa, menjadi sekitar 25 provinsi dan 500 kabupaten kota. Pulau Jawa dengan luas $130.000 \mathrm{~km}^{2}$, pada tahun 2010 penduduk sekitar 137 juta jiwa, menjadi sekitar 30 provinsi dan 700 kabupaten/kota. Kalimantan dengan luas sekitar $508.000 \mathrm{~km}^{2}$, pada tahun 2010 penduduk sekitar 14 juta jiwa, menjadi sekitar 20 provinsi dan 300 kabupaten/ kota. Sulawesi dengan luas sekitar 194.000 $\mathrm{km}^{2}$, pada tahun 2010 penduduk sekitar 17,5 juta jiwa, menjadi sekitar 10 provinsi dan 200 kabupaten/kota.Papua dengan luas sekitar $425.00 \mathrm{~km}^{2}$, pada tahun 2010 penduduk sekitar juta, menjadi sekitar 5 provinsi dan 100 kabupaten/kota.

Wilayah lainnya menjadi sekitar 10 provinsi dan 200 kabupaten/kota. Pulau atau kepulauan yang cukup besar seperti Nias, Madura, Lombok, Sumbawa, Sumba, Timor Barat, Flores dan Buton, masing-masing menjadi provinsi. Kepulauan Sangir Talaud dan Maluku Tenggara, walaupun tidak terlalu luas dan tidak banyak penduduknya, tetapi oleh karena letaknya terpencil membutuhkan kekuasaan negara yang lebih besar, dan oleh karena itu sebaiknya dijadikan propinsi. Demikian pula dengan daerah-daerah di pegunungan yang penduduknya cukup banyak, otonomi daerahnya perlu ditingkatkan, seperti Tana Toraja akan lebih baik kalau dijadikan provinsi. Kepulauan Karimun Jawa di Jawa Tengah juga jauh dari daratan Jawa Tengah, dan agar daerah ini dapat lebih cepat maju, maka dibutuhkan pemerintahan daerah yang lebih kuat dan otonom dan oleh karena itu sebaiknya ditingkatkan menjadi kabupaten. Selanjutnya masih banyak lagi pulau-pulau terpencil, terutama di bagian terluar wilayah Indonesia, 
dalam upaya mempercepat kemajuan wilayah tersebut, sekaligus dalam upaya mempertahankan keberadaannya di Indonesia, walaupun kurang luas dengan penduduk sedikit (misalnya sekitar 10.000 jiwa) perlu dipertimbangkan untuk dijadikan kabupaten atau kota.

DKI Jakarta dengan penduduk sekitar 9,5 juta orang, otonomi hanya diberikan kepada pemerintahan daerah provinsi. Dengan alasan yang sama sebaiknya dibentuk sekitar 20 kota otonom. Dan kepada Pemerintahan Kelurahan juga diberikan otonomi daerah. Kota-kota besar seperti Medan, Palembang, Bandung, Semarang, Surabaya, dan Makasar, dibagi menjadi beberapa kota otonom, dan ditambah dengan daerah sekitarnya, dijadikan provinsi. Dengan demikian terbentuk kota yang lebih kecil.

Semua upaya di atas adalah bagian dari upaya menyebarluaskan kekuasaan negara keseluruh wilayah negara, sehingga tidak ada lagi daerah yang terisolasi. Semua mendapat kesempatan yang sama untuk maju.Terserah kepada masyarakat di masing-masing daerah untuk memanfaatkan kekuasaan pemerintahan daerah beserta dana dan fasilitas yang tersedia untuk kemajuan bersama.

Pemerataan kekuasaan negara keseluruh wilayah negara, akan mendekatkannya kepada seluruh rakyat si pemilik negara untuk memperkuat kendali rakyat terhadap negara. Kalau sasaran di atas tercapai, dengan kabupaten/kota yang penduduk dan wilayahnya lebih kecil ini,maka pencalonan bupati, walikota, dan anggota DPRD kabupaten/kota sebaiknya dilakukan langsung oleh warganegara tanpa melalui partai politik. Pusat-pusat kekuasaan negara akan tersebar luas di seluruh wilayah negara, dan kondisi seperti ini akan kondusif bagi pengendalian proses penyelenggaraan pemerintahan daerah oleh rakyat, dan bagi pemerintahan daerah akan mempermudah penentuan berbagai pelayanan publik yang tepat dan cepat.

Keuntungan lain dari banyaknya provinsi, kabupaten dan kota, akan membuat gaji dan fasilitas anggota DPRD, gubernur, bupati dan walikota menjadi lebih kecil, sehingga jabatan ini tidak dapat digunakan untuk menjadi kaya dan bersenang-senang, Kondisi seperti ini mendukung penerapan etika politik. Pejabat negara dipercayai rakyat untuk melayani rakyat, bukan melayani kepentingannya sendiri, oleh karena itu menjadi kaya karena jabatan kenegaraan adalah sesuatu yang tidak etis. Di negara-negara demokrasi, biasanya gaji seorang pejabat negara lebih rendah dari gaji pejabat yang setingkat diperusahaan swasta. Ke depan ini diharapkan warganegara yang mencalonkan diri menjadi pejabat negara, termasuk menjadi anggota DPRD, gubernur, bupati dan walikota adalah warganegara yang ingin melayani masyarakat lebih baik dari sebelumnya,dan bukan karena ingin menambah kekayaan.

\section{Pembaruan Perilaku Masyarakat}

Demokrasi membutuhkan perubahan strutur dan prosedur kenegaraan, dan pada yang sama juga menuntut perubahan pemikiran dan perilaku 
masyarakat. Karena proses politik adalah interaksi antara negara dan masyarakat. Interaksi ini akan berjalan lancar dan konstruktif, kalau baik negara maupun masyarakat mengikuti aturan demokrasi. Semua aksi, baik yang dilakukan oleh negara maupun masyarakat berlangsung dengan damai, dialogal dan saling menghormati. Harus selalu disadari, bahwa semua kegiatan politik bertujuan untuk kepentingan bersama. Demokrasi mempunyai cara dan tujuan tertentu,yaitu demokrasi. Bagi demokrasi cara dan tujuan sama pentingnya. Oleh karena itu,walaupun pengambilan keputusan menjadi lambat, tetapi prosedur demokrasi harus dijalani. Berbeda dengan pemerintahan diktator yang dapat melaksanakan segala cara demi pencapaian tujuan, dengan semboyan,tujuan membenarkan cara. Demokrasi memang bukan pemerintahan demi efisiensi, tetapi pemerintahan demi tanggung jawab. Tetapi sekali keputusan ditetapkan, dapat diharapkan lapisan luas masyarakat akan mendukung.Tatanan pemerintahan negara yang demokratis akan didukung oleh warganegara dengan kepribadian demokratis, yaitu kepribadian yang matang dalam berpikir, emosi dan intelektual. ${ }^{13}$

Masyarakat perlu terlebih dahulu mendemokratisasikan dirinya sendiri, sebelum berjuang mewujudkan demokrasi dalam kehidupan kenegaraan. Kepribadian demokratis dikembangkan di kalangan masyarakat luas, dari hari ke hari semakin luas dan mendalam,hingga terwujud budaya demokrasi. Proses ini membutuhkan waktu yang lama,tetapi harus berjalan, agar konsolidasi demokrasi berhasil. Ukuran waktunya bukan tahun, tetapi generasi, dari generasi yang satu berlanjut ke generasi berikutnya. Orang dewasa yang sudah matang ini mandiri dalam berpikir, emosi dan intelektual, dapat mengatur dirinya sendiri dan tidak tergantung pada orang lain. Mereka berani mengambil keputusan sendiri dan berani memikul tanggung jawab. Kepribadian yang demokratis dapat terbentuk kalau kepada orang tersebut diberikan kebebasan untuk memilih dan mungkin saja melakukan kesalahan. Seorang tumbuh, belajar membuat pilihan-pilihan dan sekali-kali membuat pilihan yang salah.

Kepribadian demokratis lebih mengutamakan kelompok ketimbang pemimpin, dan lebih toleran, dapat menerima perbedaan sebagai sesuatu yang sehat dan wajar, dan oleh karena itu lebih mudah bekerjasama dengan orang lain.Sebaliknya, kepribadian otoriter menampilkan orang dewasa yang tidak matang. Orang ini sudah dewasa tetapi kekanak-kanakan dan sangat tergantung kepada pihak lain. Sangat mengutamakan pemimpin yang kharismatik yang akan dijadikan "gantungan". Kepribadian otoriter memandang pemimpin negara dengan campuran antara rasa hormat dan kesetiaan, seperti yang pada mulanya ditujukan kepada ayahnya. Orang-orang ini menganggap kepala negara sebagai "bapak bangsa". Kepribadian otoriter kurang toleran, dan tidak mudah menerima perbedaan pendapat. Mereka lebih menyukai kepatuhan dan keseragaman. Kalau seseorang dengan kepribadian demokratis menjadi pemimpin, biasanya akan menjadi pemimpin yang demokratis, dan sebaliknya seseorang dengan 
kepribadian otoriter akan menjadi pemimpin yang otoriter pula. Baik kepribadian demokratis maupun kepribadian otoriter tumbuh dan berkembang dari hasil belajar. Pendidikan yang otoriter cenderung mengajarkan tentang "apa". Sedangkan pendidikan yang demokratis mengajarkan tentang "mengapa" dan "bagaimana", yang akan menghasilkan orang-orang yang kritis dan kreatif.

Perbedaan pendapat tentang berbagai pikiran, diselesaikan dengan dialog dan debat yang tetap menjamin kebebasan setiap peserta untuk membela pendapatnya. Kesadaran dan sikap seperti diatas akan menumbuh-kembangkan sikap toleransi terhadap berbagai perbedaan yang terjadi di masyarakat. Toleransi adalah sikap menghormati kebebasan orang lain. Toleransi berarti mengakui hak menentukan sendiri yang dimiliki orang lain. Kebebasan pribadi harus mendapat perlindungan dari tirani penguasa dan tirani pendapat mayoritas. Walaupun kehendak mayoritas akan menjadi kebijakan negara, tetapi harus dihindari perampasan kebebasan pribadi. Toleransi dibutuhkan oleh karena disadari tidak ada manusia yang mempunyai kebenaran mutlak dan berlaku sepanjang masa. Toleransi juga perasaan yang jujur dari dalam diri manusia, bahwa mungkin saja kebenaran ada di pihak lain. Individu yang bersikap toleran mendengarkan pendapat yang dianggap salah, menyanggahnya dengan adu argumentasi dan tidak menyerang pribadi yang mengemukakan pendapat tersebut. Individu yang toleran lebih mudah berdialog dan bekerja sama dengan orang lain. Dalam diskusi, setiap pemikiran diuji kelebihan dan kekurangannya, dan melalui berbagai diskusi dapat ditemukan sintesa dari berbagai pemikiran, yang lebih mendekati kebenaran daripada pendapat sendiri yang terisolasi. Sintesa seperti ini memberikan kemungkinan lebih besar untuk menghasilkan keputusan yang baik. Pandangan-pandangan asing, pemikiran yang aneh dan cara-cara baru yang ditawarkan dalam diskusi-diskusi akan memperkaya kehidupan individu dan masyarakat. Dalam memperjuangkan demokrasi, kadangkala dibutuhkan pembangkangan sipil.

Pembangkangan sipil (civil disobedience) adalah suatu aksi publik, nonkekerasan, ungkapan hatinurani dalam kegiatan politik, melanggar hukum, biasanya bertujuan mewujudkan perubahan undang-undang atau kebijakan Pemerintah. ${ }^{14}$ Pembangkangan sipil membela suatu prinsip penting, yang dalam sejarah demokrasi mempunyai tempat terhormat. Pembangkangan sipil harus dibedakan dari pelanggaran hukum kriminal, dengan melihat cara dan tujuan politisnya dan dengan melihat kenyataan bahwa mereka yang terlibat tidak berusaha menghindari hukuman atas pelanggarannya.Tujuan pembangkangan sipil biasanya untuk melawan ketidakadilan yang dibuat oleh pejabat publik, agar diadakan perubahan kebijakan publik kearah yang lebih baik dan lebih adil. Pembangkangan sipil seyogianya dilakukan dalam kondisi yang luar biasa, dan hanya sebagai langkah terakhir. Pembangkangan sipil yang dilaksanakan oleh Dr. 
Martin Luther King Jr dan pengikutnya dengan tidak mentaati Undang-Undang Segregasi adalah satu contoh keberhasilan dari pembangkangan sipil. ${ }^{15}$

\section{Pembaruan Perilaku Negara}

Perilaku negara yang buruk harus diubah,menjadi negara yang demokratis, adil, melayani seluruh rakyat, dan bertanggung jawab. Dan agar negara mau menjadi demokratis, adil dan melayani seluruh rakyat, harus terjadi interaksi yang seimbang, adil dan saling mempercayai antara negara dengan masyarakat. Untuk itu perilaku negara dan masyarakat harus diperbarui. Negara harus dapat menegakkan keadilan, dan untuk itu negara juga harus dapat "dihukum" kalau dia bersalah kepada masyarakat,sebagaimana negara menghukum warga masyarakat yang bersalah. Pejabat negara yang bersalah dihukum dan kerugian masyarakat yang diakibatkan kesalahan pejabat negara harus diganti oleh negara. Negara walaupun bersalah tidak dapat dimasukkan kedalam penjara, oleh karena itu yang dipenjarakan adalah pejabat negaranya, sedangkan negara membayar ganti rugi.

Sesuai dengan pemikiran ini, Sengkon dan Karta seharusnya mendapat ganti rugi, tetapi sulit dilaksanakan karena belum ada undang-undang yang mengaturnya. ${ }^{16}$ Dan untuk menutupi kekurangan ini perlu ditetapkan UndangUndang Ganti Rugi, yang antara lain mengatur tentang tindakan negara yang dapat dimintakan ganti rugi, bagaimana tuntutan itu dilaksanakan; bagaimana menghitung kerugiannya; dan bagaimana pengadilannya.Perlu dibentuk Pengadilan Ganti Rugi, dengan sebagian hakim dan jaksa nonkarir,agar pengadilan dapat berlangsung adil.

Rakyat memberikan legitimasi dan kewenangan pemerintahan negara,yang dinyatakan dalam suatu iklim politik terbuka dan bebas, melalui pemilihan umum yang adil, bebas, kompetitif dan berkala. Setiap warganegara memilih individu-individu yang akan memerintah serta menurunkan pemerintah yang ada. Pemilihan umum yang bebas mendorong pemerintah memberikan

15 Lihat Mochtar Lubis (Peny). 1994. Demokrasi Klasik dan Modern. Jakarta: Yayasan Obor Indonesia. Hal. 223.

16 Sengkon dan Karta dituduh membunuh pasangan Sulaiman-Siti Haya,dan pada Oktober 1977 Sengkon divonis 12 tahun dan Karta 7 tahun penjara. Di dalam penjara Sengkon dan Karta ketemu Genul yang membunuh pasangan Sulaiman-Siti nya diajukan ke pengadilan dan divonis 12 tahun.Meskipun pembunuh yang sebenarnya telah divonis, Sengkon dan Karta tidak langsung bebas,karena keduanya tidak mengajukan banding hingga keputusan terhadap kedua orang ini dianggap telah mempunyai kekuatan hukum tetap. Albert Hasibuan, seorang pengacara, memperjuangkan pembebasan Sengkon dan Karta, dan pada Januari 1981,Ketua Mahkamah Agung Oemar Seno Aji memerintahkan agar keduanya dibebaskan lewat jalur peninjauan kembali. Terhadap ketidakadilan negara ini, Sengkon dan Karta menuntut ganti rugi Rp 100 juta, Tuntutan berpindah dari satu Pengadilan ke Pengadilan yang lain, tetapi negara tetap tidak memberi ganti rugi.Negara sangat tidak adil,karena negara telah berlaku tidak adil kepada Sengkon dan Karta sebanyak 2 kali, pertama menghukum mereka yang tidak bersalah dan kedua tidak mau memberi ganti rugi. 
pertanggungjawaban kepada rakyat dan mencegah timbulnya kekuasaan negara yang lepas dari kendali rakyat. Pemilihan umum yang bebas dan adil hanya dapat dilakukan dalam negara demokrasi, karena demokrasi menjamin kebebasan dan kesetaraan politik dan menjamin pemenuhan hak asasi manusia. Dalam demokrasi,negara dapat melindungi dirinya sendiri bersamaan dengan melindungi rakyat,karena negara berada di tangan rakyat. Kepentingan negara tidak bertentangan dengan kepentingan rakyat, karena kemajuan rakyat adalah juga kemajuan negara, demikian pula sebaliknya. Kemajuan masyarakat tidak akan terjadi tanpa ada kebebasan,karena kemajuan membutuhkan kreativitas individu dan masyarakat, dan kreativitas membutuhkan kebebasan.

Demokrasi dan hak asasi manusia adalah dua fenomena yang berbeda. Demokrasi berbicara tentang tatanan kenegaraan seperti pemilihan umum, multi partai, pemisahan kekuasaan, sedangkan hak asasi manusia fokus pada individu.Tetapi demokrasi dan hak asasi manusia saling membutuhkan, berdasarkan pengertian bahwa hak-hak sipil dan politik adalah bagian dari demokrasi, dan hak-hak sipil dan politik adalah bagian dari hak asasi manusia.Tidak mungkin terwujud negara demokrasi tanpa jaminan terhadap hak asasi manusia.Tanpa kebebasan berbicara, kebebasan berserikat, kebebasan bergerak, atau jaminan keamanan perorangan, pemilihan umum yang demokratis sebagai kendali rakyat terhadap pemerintahan negara tidak dapat dilakukan.Pemikiran ini dapat terlihat dalam proses pendirian dan penyelenggaraan negara demokrasi. Salah satu komponen penting dalam konstitusi negara demokrasi hak asasi manusia,yang biasanya telah ditetapkan dalam konstitusi sejak awal pendirian negara. Namun demikian,pemenuhan hak asasi manusia tidak selalu mudah,dan sering masih membutuhkan perjuangan berat. Tetapi selama negara tersebut masih tetap negara demokrasi, tuntutan terhadap pemenuhan hak asasi manusia akan tetap berjalan dan pelaksanaannya akan terus maju, walaupun secara bertahap.

\section{Penutup}

Penyelenggaraan negara adalah untuk meningkatkan kesejahteraan dan keamanan seluruh rakyat. Tetapi di era orde baru ketidakadilan terjadi hampir di semua aspek kehidupan, dan kemudian menyisakan kemiskinan yang luas, pengangguran yang terlalu banyak, korupsi yang merajalela dan keterbelakangan pendidikan.

Reformasi telah berlangsung lebih dari 10 tahun, dan telah dicapai beberapa kemajuan politik, tetapi di bidang ekonomi,penegakan hukum dan pemberantasan korupsi,kebebasan beragama dan sosial budaya kita belum pulih.

Pengangguran dan penduduk miskin tetap banyak, konflik kekerasan antar berbagai kelompok masyarakat masih sering terjadi dengan korban jiwa dan harta,intoleransi atas dasar agama/kepercayaan meningkat, teror massa berkembang, dan kerusakan lingkungan hidup belum dapat ditanggulangi. 
Korupsi tetap merajalela,bahkan meluas sampai keseluruh nusantara,melibatkan banyak pejabat negara dari lembaga eksekutif, legislatif dan yudikatif. Kondisi seperti ini terjadi karena penyelenggaraan negara sering lepas dari kendali rakyat.

Rakyat harus mengendalikan negara,karena kalau negara lepas dari kendali rakyat,negara yang besar kekuasaannya itu akan disalahgunakan untuk kepentingan pejabat negara,dan sekaligus melupakan rakyat Negara adalah alat milik rakyat yang didirikan untuk kebaikan bersama, dan negara yang seperti itu adalah negara demokrasi,yang proses penyelenggaraannya harus selalu berada dalam kendali rakyat. Berbagai cara dilaksanakan untuk mengendalikan negara, antara lain: membatasi kekuasaan negara, mendistribusikan kekuasaan negara dengan menggunakan prinsip checks and balances, pemilihan umum yang bebas, adil, kompetitif dan berkala, dan mendekatkan kekuasaan negara kepada rakyat dengan melaksanakan otonomi daerah dalam daerah otonom yang tidak terlalu luas dan atau terlalu banyak penduduknya.

Kekuasaan negara harus dibatasi, agar rakyat dapat mengendalikan negara. Pembagian kekuasaan negara dengan prinsip checks and balances memungkinkan rakyat menggunakan satu lembaga negara mengkoreksi kekeliruan lembaga negara yang lain. Pemilihan umum memberi kesempatan kepada rakyat memilih warganegara yang tepat menjadi pejabat negara, dan pada saat yang sama menurunkan pejabat negara yang gagal.

Otonomi daerah mendekatkan kekuasaan negara kepada rakyat, agar rakyat dapat lebih mudah mengendalikaan proses pemerintahan daerah sebagai bagian dari pengendalian penyelenggaraan negara.

Untuk itu penambahan daerah otonom perlu dilakukan lebih cepat, agar masing-masing daerah otonom tidak terlalu luas dan atau terlalu banyak penduduknya. Diusulkan sampai dengan tahun 2020 Indonesia memiliki sekitar 100 provinsi dan sekitar 2000 kabupaten/kota.

Baik negara maupun masyarakat harus memperbarui perilakunya menjadi lebih demokratis,agar interaksi politik negara-masyarakat dapat berlangsung dengan damai,adil,seimbang dan saling mempercayai.

\section{Daftar Pustaka}

Bahar, Saafroedin dkk. (peny). 1995. Risalah Sidang Badan Penyelidik Usaha Persiapan Kemerdekaan Indonesia (BPUPKI), Sekretariat Negara Republik Indonesia.

Beetham, David.1999. Democracy and Human Rights. Cambridge: Polity Press.

Ebenstein, William dkk. 1994. Isme-isme Dewasa ini. Jakarta: Penerbit Erlangga.

"Kota Marikina di Filipina Melejit karena Desentralisasi". Harian Kompas, 26 April 2001. 
Haris, Syamsudin (ed).1998. Menggugat Pemilihan Umum Orde Baru. Jakarta: Yayasan Obor Indonesia.

Huntington, Samuel P. 1995. Gelombang Demokratisasi Ketiga. Jakarta: Penerbit PT Pustaka Utama Grafiti.

Hatta, Mohammad. 1976. Kumpulan Karangan. Jakarta: Penerbit Bulan Bintang.

Locke. John. 2006. Kuasa itu Milik Rakyat. Yogyakarta: Penerbit Kanisius.

Lubis. Mochtar 1994. Demokrasi Klasik dan Modern. Jakarta: Yayasan Obor Indonesia.

Panjaitan, Merphin. 2001. Gerakan Warganegara Menuju Demokrasi. Jakarta: Penerbit Restu Agung.

. 2011. Logika Demokrasi: Rakyat Mengendalikan Negara. Jakarta: Penerbit Permata Aksara.

Perserikatan Bangsa-Bangsa. 1948. Deklarasi Universal Hak Asasi Manusia

Rachbini, Didik J. 2001. Ekonomi di Era Transisi Demokrasi. Jakarta: Penerbit Ghalia Indonesia.

Rawls, John. 2006. Teori Keadilan. Yogyakarta: Penerbit Pustaka Pelajar.

Republik Indonesia. Undang-Undang Dasar Negara Republik Indonesia Tahun 1945 dan Perubahannya.

Schumpeter, Joseph A. 1950. Capitalism, Socialism, and Democracy. New York: Harper and Brothers Publishers.

Sodaru, Michael J. 2006. Comparative Politics A Global Introduction. New York: Mc Graw Hill.

Suseno, Frans Magnis. 1991. Etika Politik. Jakarta: Penerbit PT Gramedia. 